\title{
A new Miocene deep-sea chiton and early evidence for Teredinidae-sustained wood-fall communities
}

\author{
Luca Bertolaso, Vittorio Garilli, Daniela Parrinello, Maurizio Sosso, \\ and Bruno Dell'Angelo
}

\begin{abstract}
Deep-sea wood-falls are important biodiversity hot spots for insights on chemosynthesis-based communities. The study of deep-sea wood-fall-related palaeocommunities from the Neogene of north Italy shed light on interesting associations from the Miocene of Torrente Cinghio (Tortonian) and of Moncasale di Casina (Langhian). The most common components of this association are typical chemosynthetic/wood-fall molluscs, such as the gastropods Homalopoma sp. and Pseudonina bellardii, the bivalves Idas sp. and shipworms, and the chiton Leptochiton lignatilis $\mathrm{n}$. $\mathrm{sp}$., which belongs to a genus typical of recent sunken woods in tropical waters. The new species described is compared with other fossil and recent congeners, especially with those sharing the same kind of tegmental sculpture, fully covered with randomly or quincuncially arranged granules. An overview of the sunken wood-related chitons is provided. Surprisingly no taxa of the boring bivalves of the family Xylophagidae, whose species have been known to be fundamental for sustaining this kind of deep sea chemosynthetic ecosystem, were found in the studied site; however, other boring Teredinidae bivalves have been abundantly recovered. This suggests that, conversely to what has previously been observed on sunken wood communities, Teredinidae may be viewed as a counterpart for the maintenance of deep-sea wood-fall ecosystems.
\end{abstract}

Luca Bertolaso. Via Manzotti 35, 42015 Correggio (RE), Italy. bdimit@tin.it

Vittorio Garilli (corresponding author). Paleosofia - APEMA Research \& Educational Service, Via Alla Falconara, 34, 90136 Palermo, Italy. vittoriogarilli@apema.eu

Daniela Parrinello. Department of Biological, Chemical and Pharmaceutical Science and Technology,

"Animal Biology Section", University of Palermo, Via Archirafi 18, 90100 Palermo, Italy.

daniela.parrinello@unipa.it

Maurizio Sosso. Via Bengasi 4, 16153, Genova, Italy. sosmauri@gmail.com

Bruno Dell'Angelo. Museo di Zoologia, Via Selmi 3, 40126 Bologna, Italy. bruno.dellangelo@chitons.it

Keywords: wood-fall; Polyplacophora; new species; Teredinidae boring bivalves; Miocene; Mediterranean area

Submission: 21 March 2015. Acceptance: 9 July 2015

http://zoobank.org/17950F77-D49D-4D22-A0FD-77240FD36070

Bertolaso, Luca, Garilli, Vittorio, Parrinello, Daniela, Sosso, Maurizio, and Dell'Angelo, Bruno. 2015. A new Miocene deep-sea chiton and early evidence for Teredinidae-sustained wood-fall communities. Palaeontologia Electronica 18.2.41A: 1-15

palaeo-electronica.org/content/2015/1277-miocene-wood-fall-community

Copyright: Palaeontological Association August 2015 


\section{INTRODUCTION}

Large nekton and wood-falls are important local resources of organic carbon in otherwise oligotropic deep-sea environments. Recently an artificial deployment of a wood-fall in the Central Nile deep-sea fan delta in the Eastern Mediterranean (Bienhold et al., 2013) showed that, after only one year, the presence of wood on the seafloor led to the creation of lower oxygen and sulfidic conditions, prerequisites for colonization by specialized and/or opportunistic wood-fall fauna. As suggested by Distel et al. (2000), whale falls, wood-falls and other organic falls may provide important steps for the introduction of recent benthos to vents and seeps biota. Kaim et al. (2008) achieved similar conclusions for the fossil record, postulating the role of Mesozoic marine reptile carcasses as evolutionary and dispersal stepping stones. Moreover, studies by McClain and Barry (2014) on woods deployed on deep-sea bottoms have provided convincing estimates of how wood-fall environments may contribute to biodiversity.

Many observations on naturally sunken and deployed woods (e.g., Bernardino et al., 2010; Samadi et al., 2010; Heise et al., 2011) have highlighted the importance of factors such as wood type and size, position on wood logs, time after deployment, water temperature and depth in influencing the pattern of wood colonization, a situation analogous to that evidenced for whale falls (e.g., Lundsten et al., 2010).

The wood-boring bivalves of the family Xylophagidae Purchon, 1941 are the main colonizers of naturally and artificially sunken woods in deep water, usually in 400-3203 m (Turner, 2002; Voight, $2007,2015)$. These bivalves have an important role in the initial degradation of the wood, as they transform the energy accumulated in the wood tissue into nutrients that are available for other animals (Turner, 1973, 1978). This transformation is accomplished by both the decomposition of woody material and the contribution of faecal pellets and larval stages that rain down to the sediment surface (Bernardino et al., 2010), setting up the best conditions for bacterial exploitation and for activating a chemosynthesis-based chain. The development of a chemically reducing habitat allows for the colonization of taxa capable of sustaining elevated concentrations of sulfide.

The drifting/floating wood may, however, be colonized by bivalves of the family Teredinidae Rafinesque, 1815. Some of these bivalves have been found alive in sunken wood retrieved from the deep sea (Turner, 1968; Nair and Saraswathy,
1971; McKoy, 1980; Pailleret et al., 2007; Saito, 2013; Voight, 2015 with other references therein), but it is still not clear how long they can survive at such depths or, at least, whether "the considerable time they may survive" (Turner, 1968) is enough for maintaining a chemosynthetic ecosystem. Evidence is likewise lacking for the possibility of teredinid larval colonization of deep-water wood-falls (Turner, 1968), because it has so far only been detected at shallow depths, from 7.6-25.9 m (Edmonson, 1962) to $60.9 \mathrm{~m}$ (Haderlie and Mellor, 1973), with increased settlement of some species at greater depths (Quayle, 1992 and references therein). Wood deployed on a 183-267 m deep bottom near the Bahamas, however, was recovered with two teredinid species (Heise et al., 2011).

Apart from the boring bivalves, other specialized, opportunistic molluscs may colonize sunken wood on deep bottoms, whereas colonizers at shallow sites are unspecialized species that are normally present in the background fauna (Santhakumaram and Sneli, 1984; Berg et al., 1987). For example, several taxa in the class Polyplacophora Gray, 1821 (i.e., chitons), particularly in Lepidopleurida Thiele, 1909, may colonize sunken wood in deep waters. Chitons are closely related to, and in some cases specialized for, this kind of substrate especially in tropical waters. Documentation of chitons in the fossil record that are related to wood-fall ecosystems are generally rare, however, thus making the origin of their possible specialization on wooden substrates, as well their phylogenetic relationship, a matter of debate.

Here we describe the first results of taxonomic and palaeoecological analyses of the invertebrate assemblages from some Italian Neogene deposits along the foothills of the northern Apennine Mountains, with special regard to molluscs from organicrich marine palaeoenvironments. Specifically the goals of this work are to characterize the main molluscan species recovered from a wood-fall association, which is the first described Italian Miocene wood-fall deposit, and to provide preliminarily discussion of the role of boring Teredinidae bivalves in the trophic structure of a deepsea wood-fall community. Our report also includes the description of a new species of the chiton genus Leptochiton Gray, 1847.

\section{Geological Setting and Stratigraphy of the Study Sites}

The study sites are located in the domains resulting from a compressional tectonic regime, between the Adriatic-Apulian foreland structural 


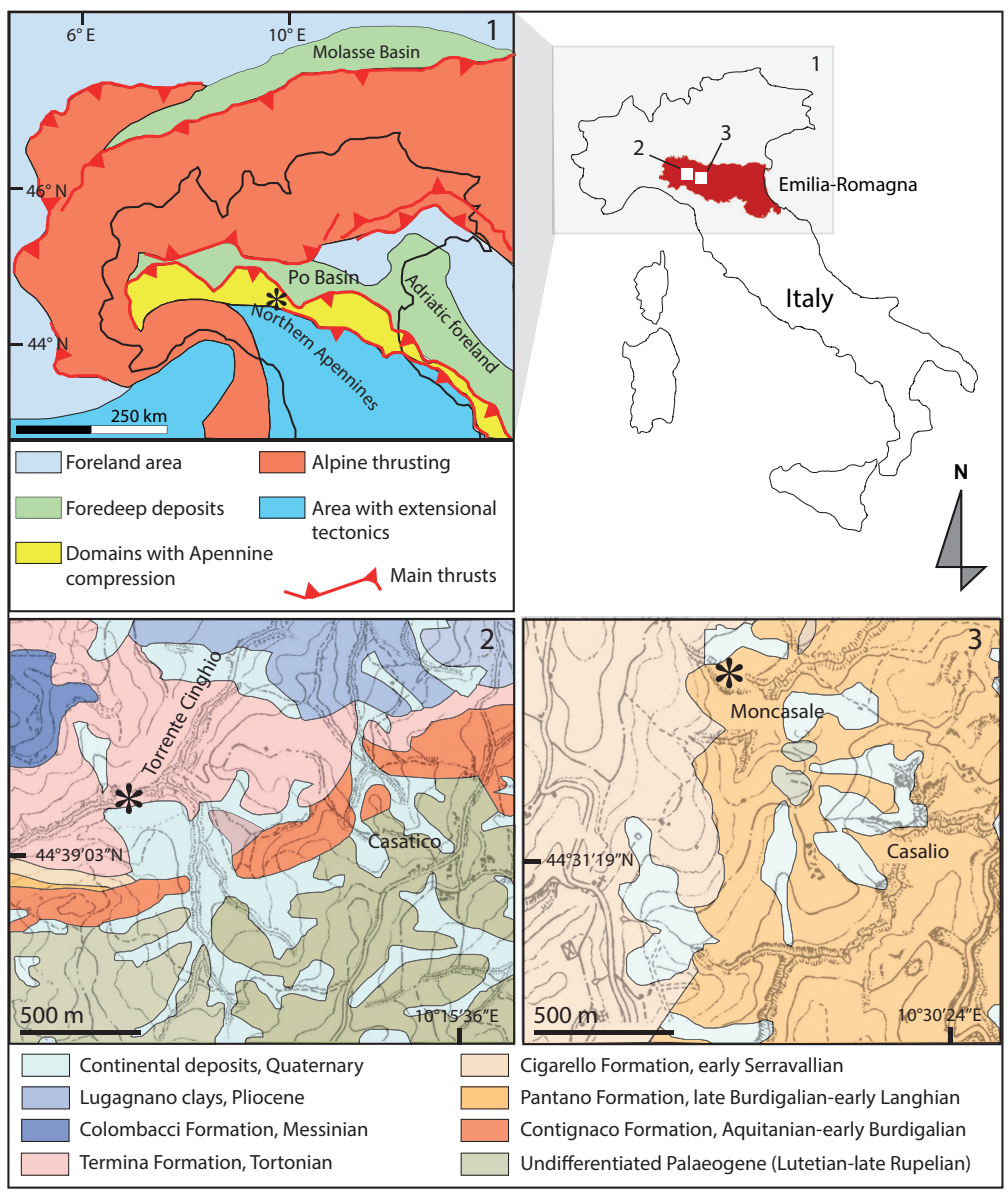

FIGURE 1. Location of the study area and of the Torrente Cinghio and Moncasale sites (asterisks) in the structural map (1) of northern Italy (modified from Scrocca et al., 2003) and in their respective geological setting (2-3) as modified from Papani (2002) and Di Dio and Zanzucchi (2005).

domain and the main thrust of the Northern Apennines (Figure 1.1), a rapidly migrating thrust belt developed mainly in Neogene times during the eastward roll-back of the subducting Adriatic plate (Scrocca et al., 2003).

Most of the studied material comes from the sediments of the Torrente Cinghio site (Figure 1.2). These sediments belong to the "Formazione del Termina" (Termina Fm) (Bettelli et al., 1989) that ranges from the late Serravallian to the late Tortonian, occasionally to the early Messinian (Miculan, 1992; Gasperi et al., 2005). In particular this site is middle to late Tortonian in age as the biozones MNN8a, MNN8b and MNN9 have been recognized (Fornaciari et al., 1996). The Termina Fm is a muddy unit at the end of a deepening-upward succession filling the Emilian basin, overlying coarser deposits of the Pantano Fm and the Cigarello Fm (Di Dio et al., 2005). Other material has been recovered near Moncasale di Casina (Reggio
Emilia, $\mathrm{N}$ Italy), in a gully situated on the left side of the "Fosso di Moncasale" (Figure 1.3). The lower and middle parts of the exposure belong to the Pantano Fm, aged late Burdigalian - Langhian (Amorosi et al., 1993). This material comes from sediment that contains Praeorbulina glomerosa circularis Blow, 1956 (P. Miculan, personal commun., 1995), suggestive of the middle Langhian biozone MMi4b (laccarino and Salvatorini, 1982; Di Stefano et al., 2008), or, at least a middle-late Langhian age as this foraminifer does not occur in younger sediments (Ryan et al., 1979).

\section{Chitons on Sunken Wood}

Within the order Lepidopleurida, the families Ferreiraellidae Dell'Angelo and Palazzi, 1991, Nierstraszellidae Sirenko, 1992 and a part of Leptochitonidae Dall, 1889 seem to have a close relationship with wood-falls, and many species are found in abundance on tropical sunken wood (Sig- 
wart and Sirenko, 2012). On the basis of the strong similarity between the recent Ferreiraella Sirenko, 1988 (with most species living on sunken woods, Sigwart and Sirenko, 2012) and the Carboniferous Glaphurochiton Raymond, 1910, Sirenko (2004) suggested that wood-falls might have formed deep-sea habitats for chitons since the Middle to Late Palaeozoic when large woody plants first evolved on land (Wolff, 1979). Sirenko (2004) also inferred a post-Jurassic origin of the Leptochiton specialization on wood, later than the first occurrence of the family Leptochitonidae, a Carboniferous origin for Ferreiraellidae, and a late Mesozoic origin for Nierstraszella Sirenko, 1992. Proposals of ancient origins for deep-sea taxa should be treated cautiously, however, as well as the Palaeozoic origin of the specialization on wood substrates because their fossil record is not extensively known. In addition, Glaphurochiton was not found associated with fossil wood, but in black and dark shales assumed to be a palaeoenvironment rich in organic material (Kiel and Goedert, 2006a). The three families also have shell features that are generally interpreted as plesiomorphic so that it is difficult to pinpoint their origin in the fossil record.

One of Sirenko's (2004) main arguments for a phylogenetic association between the Palaeozoic Glaphurochiton and the extant Ferreiraella chitons living on sunken wood is the current known distribution of the latter. Ferreiraella only occurs along the tropical western and eastern coasts of the Pacific Ocean and extends into the Caribbean Sea, which corresponds loosely to the last remaining areas of the ancient Pantalassian coast.

The two established species in the genus Nierstraszella, N. lineata (Nierstrasz, 1905) and N. andamanica (Smith, 1906), are restricted to sunken wood habitats (Sigwart, 2009; Sigwart and Sirenko, 2012). The worldwide genus Leptochiton includes species living in a wide range of habitats, from intertidal to deep waters, even if a large number of deep-water species were found on sunken wood (Sigwart and Sirenko, 2012). This genus is well disseminated in the wood-falls from the W. Pacific (Pailleret et al., 2007; Samadi et al., 2010; Duperron et al., 2013; Sigwart and Sirenko, 2012) with a single species reported from wood-falls in the Caribbean Sea, L. binghami (Boone, 1928) (Gracia and Ardila, 2004; Sirenko, 2004; Sigwart and Sirenko, 2012), and a high species diversity in the Atlantic Ocean (Kaas and Van Belle, 1985) and the Mediterranean Sea (Dell'Angelo and Smriglio, 1999). A recent molecular phylogenetic study of Lepidopleurida (Sigwart et al., 2011) showed that the genus is not monophyletic, Leptochiton and Leptochitonidae sensu stricto being restricted to North Atlantic and Mediterranean taxa. The results of that study also suggested the occurrence of two separate clades independently inhabiting sunken wood substrates in the southwestern Pacific.

There is a different trophic relationship with the wood substrate between Leptochitonidae and at least Nierstraszellidae. Sirenko (2004), studying the relationship between length of the digestive tract and content of food, regarded the "wood-fall related chitons" as detritivorous. This agrees with the analysis performed by Duperron et al. (2013) on Leptochiton boucheti Sirenko, 2001 and Nierstraszella lineata (Nierstrasz, 1905). Both species do not directly digest the wood, but instead feed on biofilms covering the decaying wood. These biofilms consist of microorganisms contributing to wood degradation and probably also suspended particulate organic matter derived from the downward flux of detritus. These two species also display associations with different bacterial partners. Leptochiton boucheti harbours Mollicutes Edward and Freundt, 1967 in regions of its gut epithelium, but has no abundant bacterium associated with its gills. Conversely, Nierstraszella lineata displays no dense gut-associated bacteria, but harbours bacterial filaments attached to its gill epithelium, related to the Deltaproteobacteria symbionts found in gills of the wood-eating limpet Pectinodonta Dall, 1882 (Zbinden et al., 2010; Duperron et al., 2013). Nierstraszella lineata, as a member of a family restricted to sunken wood, is likely better adapted to more anoxic conditions due to its gill-associated bacteria. Leptochiton boucheti is phylogenetically more proximate to an ancestral form not specialized on wood and may itself be more of a generalist, in agreement with the other members of "Leptochitonidae" whose diet has been studied. Another member of Leptochiton, L. cf. assimilis (Thiele, 1909), was recently found from sunken wood collected from the abyssal plain area off the Kuril-Kamchatka Trench (Schwabe et al., 2015) and seems to have similar feeding ecology to $L$. boucheti.

Further investigations are also needed within the more species-rich order Chitonida Thiele, 1909 to clarify the microhabitat and feeding ecology of its deep-water representatives as well as their potential specialized associations with a reducing environment or with a specialized substrate such as sunken wood. For example, Tripoplax alba Saito, 2013 from the East China Sea at depths of 576$611 \mathrm{~m}$ has been found living either on sunken 
wood or dead shells generally together with Calyptogena kawamurai (Kuroda, 1943), a bivalve that is characteristically associated with chemosynthetic communities (Saito, 2013). Two other congeners are known from chemosynthetic environments off the Chilean coast, Tripoplax balaenophila (Schwabe and Sellanes, 2004) from a $240 \mathrm{~m}$ deep whale bone and Tripoplax cowani (Clark, 2008) from a methane seep area at a depth of $922 \mathrm{~m}$ (Schwabe and Sellanes, 2004, 2010). Examples of chitons linked to sunken woods are represented by two unidentified specimens of Stenosemus Middendorff, 1847 from the Solomon Islands (Sigwart and Sirenko, 2012) and by the unidentified specimens of Ischnochitonidae Dall, 1889 and Acanthochitonidae Pilsbry, 1893 from the Vanuatu Islands (BOA1 cruise, Samadi et al., 2010).

In spite of their considerable presence in recent wood-fall, chitons clearly associated with sunken wood are rare in the fossil records and are only represented by Leptochiton species. The oldest record is that of a "leptochitonid polyplacophoran" from a Poland Middle Jurassic sunken driftwood with no associated chemosymbiotic animals due to the absence of xylophagid boring bivalves (Kaim, 2011). Leptochiton shapovalovi Sirenko, 2013 from the Late Jurassic (Oxfordian) of Russia is another possible Jurassic xylophagous species. It shows a shape similar to recent xylophagous chitons and was found in clay with numerous pieces of fossil wood, together with a gastropod species associated with biotopes of sunken wood.

Cenozoic deep-water sediments in Washington State, USA, have produced fossil wood- and whale-fall communities, which occur in close geographic and stratigraphic proximity to cold seeps (Kiel and Goedert, 2006a, 2006b). Twenty-nine molluscs (excluding shipworms) were identified from 28 wood-fall communities from the Eocene to Oligocene, and a species attributed to Leptochiton was present in five of these communities (Kiel and Goedert, 2006a). Also, a single intermediate valve of an unidentified chiton was found in a wood-fall from the Eocene of the Lincoln Creek Formation in Washington State, USA (Kiel and Goedert, 2006b).

Our description of Leptochiton lignatilis $\mathrm{n}$. $\mathrm{sp}$. from the Miocene of Italy adds a further record to the scarce number of chitons in fossil wood-fall communities.

\section{MATERIALS AND METHODS}

Most of the studied material comes from an outcrop along the banks of the stream known as
Torrente Cinghio, $625 \mathrm{~m}$ from Case Cuccarello (Torrechiara, Langhirano, Parma, N Italy, Figure 1). It specifically comes from a massive dark grey claystone within a ca. $3 \mathrm{~m}$ thick succession on the right side of the stream. This layer, at $1.5 \mathrm{~m}$ over a characteristic lens of a bluish light grey bioturbated claystone of unknown lateral extent, contains few carbonized wood remains that are concentrated within a small lens-shaped feature $(25 \mathrm{~cm}$ wide and up to $6-7 \mathrm{~cm}$ thick) surrounded by oxidized surfaces. This lenticular feature is interpreted as the "ghost" of the fossil sunken wood and gives an approximation of its size. This feature was sampled, washed and sieved (mesh sizes of 0.2, 0.5, $1.0,2.0 \mathrm{~mm}$ ), and all the organic remains were recovered. Particular attention was given to the mollusc remains for which a semiquantitative analysis was carried out, with emphasis on detecting species typical of wood-fall communities.

Further material is from the upper part of a 60$70 \mathrm{~m}$ thick succession cropping out in a gully on the left side of the "Fosso di Moncasale", near Moncasale di Casina (Reggio Emilia, N Italy, Figure 1). This material comes from a lens-shaped mudstone that is within a body resedimented by slumping.

Morphological details of Leptochiton lignatilis n. sp. were preliminarily studied using a Cambridge S-360 scanning electron microscope (SEM) at the Dipartimento di Scienze della Terra dell'Università di Torino. Further in-depth analyses were performed using LEO 420 SEM.

\section{Abbreviations}

MGPT, Museo di Geologia e Paleontologia, University of Torino, Italy; MSNG, Museo Civico di Storia Naturale Giacomo Doria, Genova, Italy; MZB, Museo di Zoologia, University of Bologna, Italy; MZPD, Museo di Zoologia P. Doderlein, University of Palermo, Italy; NHMW, Natural History Museum Wien, Austria; ZISP, Zoological Institute of the Russian Academy of Sciences, St. Petersburg, Russia; $\mathrm{BD}$, Bruno Dell'Angelo collection, Genova, Italy (will be deposited in MZB); LB, Luca Bertolaso collection, Reggio Emilia, Italy.

\section{RESULTS}

\section{The Most Common Molluscs at the Study Sites}

The analysis of the sample collected from the lens-shaped feature in the Torrente Cinghio deposit provided a relatively rich molluscan assemblage consisting of about 87 taxa, including 48 gastropods, 35 bivalves, five scaphopods and one chiton. 
Among the most common species found were: 1) approximately 100 disarticulated valves of the new chiton species, Leptochiton lignatilis n. sp.; 2) almost 300 Homalopoma sp. and more than 250 Pseudonina bellardii, both gastropod species represented by a full growth series; 3 ) about 60 valves of the bivalve Idas sp. and, among the wood-boring bivalves, several palettes, tubes and valves of Bankia sp., Psiloteredo cf. megotara (Hanley in Forbes and Hanley, 1848) and Teredotyra sp.; and 4) more than 200 valves of an undetermined species still under study belonging to Teredinidae. The occurrence of other molluscs, including the gastropod Alvania testae (Aradas and Maggiore, 1844), the bivalve Delectopecten cf. vitreus (Gmelin, 1791) and the scaphopod Entalina tetragona (Brocchi, 1814) indicate a deep-sea epibathyal environment.

A less diverse assemblage was found in the sample collected from the Moncasale site, where fossils are generally poorly preserved. In this site, however, a similar community structure was detected, with the most significant taxa being teredinids, Homalopoma sp. and Pseudonina bellardii, all represented by a great deal fewer specimens.

\section{Systematic Palaeontology}

Class POLYPLACOPHORA Gray, 1821

Family LEPTOCHITONIDAE Dall, 1889

Genus LEPTOCHITON Gray, 1847

Type species. Chiton cinereus Linnaeus, 1767 sensu Montagu, 1803 (misapplication of name, subsequently designated by Gray, 1847) = Leptochiton asellus (Gmelin, 1791) (see Sirenko, 2001, p. 41).

Distribution. Worldwide; Upper Jurassic (Sirenko, 2013) - recent.

Leptochiton lignatilis n. sp. Dell'Angelo, Bertolaso and Sosso

Figures 2-4

zoobank.org/29F12828-2C47-402C-AE6D-08CB47432214

Type material. Holotype: MGPT-PU 108787 (tail valve, Figure 2.1-4); paratypes: MGPT-PU 108788 (head valve, Figure 2.6-7); MZB 32033 (intermediate valve, Figure 3.1-2, broken during preparation for SEM); MZB 32034 (intermediate valve); NHMW 2014/0451/0001 (intermediate valve, Figure 3.3-4); NHMW 2014/0451/0002 (tail valve, Figure 2.5); ZISP 2226 (intermediate valve); ZISP 2227 (intermediate valve); MSNG 57980 (one intermediate and one head valve); MZPD MAL-2074 (intermediate valve, Figure 2.8-9); MZPD MAL-2075 (head valve). MZPD MAL-2076 (fragment of intermediate valve, Figure 3.5-8). These valves are from the Tortonian of Torrente Cinghio, Parma, Emilia Romagna, N Italy. Another paratype, MZPD MAL2077 (fragment of intermediate valve, Figure 4.12 ), is from the Langhian of Moncasale di Casina, Reggio Emilia, Emilia Romagna.

Other material examined. 100 valves, most of them incomplete, from the Tortonian of Torrente Cinghio, in BD and LB.

Type locality. Torrente Cinghio, Parma, Italy; Miocene, Tortonian.

Type horizon. Dark grey claystone of the Termina Formation, Tortonian in age.

Etymology. The name lignatilis (relating to the wood) is from the Latin lignum (wood), with referring to the substrate linked to this species.

Distribution. Leptochiton lignatilis $\mathrm{n}$. sp. is only known from the Miocene of northern Italy, particularly from the Tortonian of Torrente Cinghio (Parma), and from the Langhian of Moncasale di Casina (Reggio Emilia).

Diagnosis. Head valve semioval; intermediate valve rectangular, carinated, elevated; tail valve more than semicircular, mucro anterior. Tegmentum ornamented by irregularly arranged, well-separated roundish-subquadrangular granules.

Description. Holotype width (lateral) $3.5 \mathrm{~mm}$, length (antero-posterior) $2.5 \mathrm{~mm}$; maximum width 2.4 / 3.4 / $3.5 \mathrm{~mm}$ (head, intermediate, and tail). Head valve semioval (Figure 2.6), posterior margin widely V-shaped, slope concave. Intermediate valve broadly rectangular (Figure 3.1 ) with slightly rounded corners, carinated, anterior and posterior margins almost straight, apex indistinct, elevated (height/width 0.5), lateral areas scarcely differentiated. Tail valve more than semicircular (Figure 2.1), anterior margin convex, mucro anterior, not prominent, antemucronal slope convex, postmucronal slope a little concave just underneath mucro.

Sculpture of tegmentum formed by rather irregular elevated granules, of roundish shape (Figure 2.7), well separated from each other, irregularly arranged, except apex portion of head valve with concentric ridges. Granules become more irregularly elongate (Figure 3.5-6) towards the jugal area of intermediate valves, but always well separated, not coalescing. Each granule (diameter 40 to 50 $\mu \mathrm{m})$ bears a more or less central macroaesthete, and variable number of microaesthetes, two to four, up to five to six in more elongate granules (Figures 2.9, 3.6). Elongate granules can reach a maximum length up to $70 \mu \mathrm{m}$. 


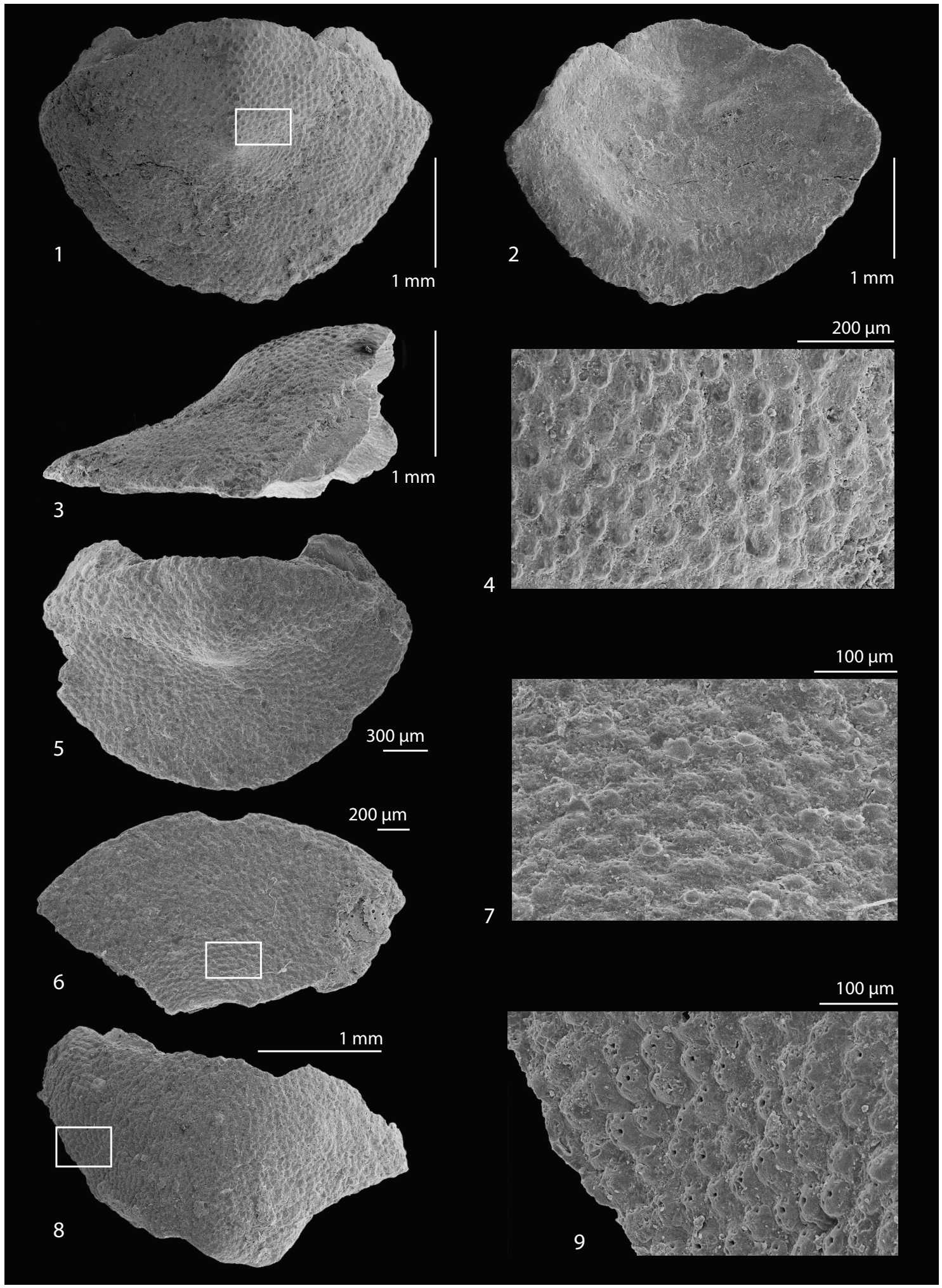

FIGURE 2. Leptochiton lignatilis $\mathrm{n}$. $\mathrm{sp}$. from the Miocene (Tortonian) of Torrente Cinghio (Parma, $\mathrm{N}$ Italy, type locality). 1-4. Holotype, tail valve MGPT-PU 108787 in dorsal (1), ventral (2) and lateral (3) views, and close up (white rectangle in 1) showing sculpture (4). 5. Paratype NHMW 2014/0451/0002, tail valve with a more protruding mucro. 6-7. Paratype MGPT-PU 108788, head valve in dorsal view (6) and close up (white rectangle in 6) showing sculpture (7). 8-9. Paratype MZPD MAL-2074, intermediate valve in dorsal view (8) and close up (white rectangle in 8) showing granules with aesthetes (9). 


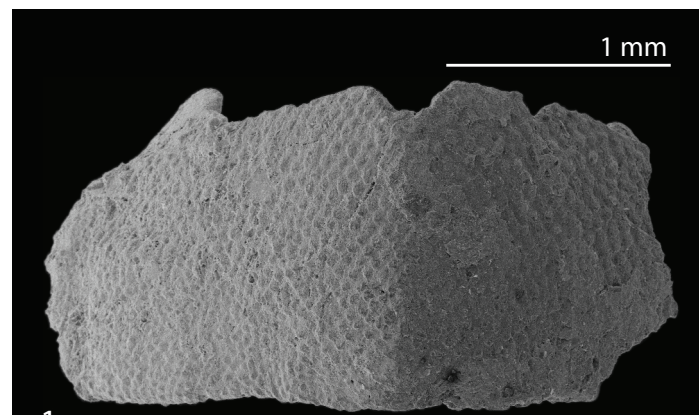

1
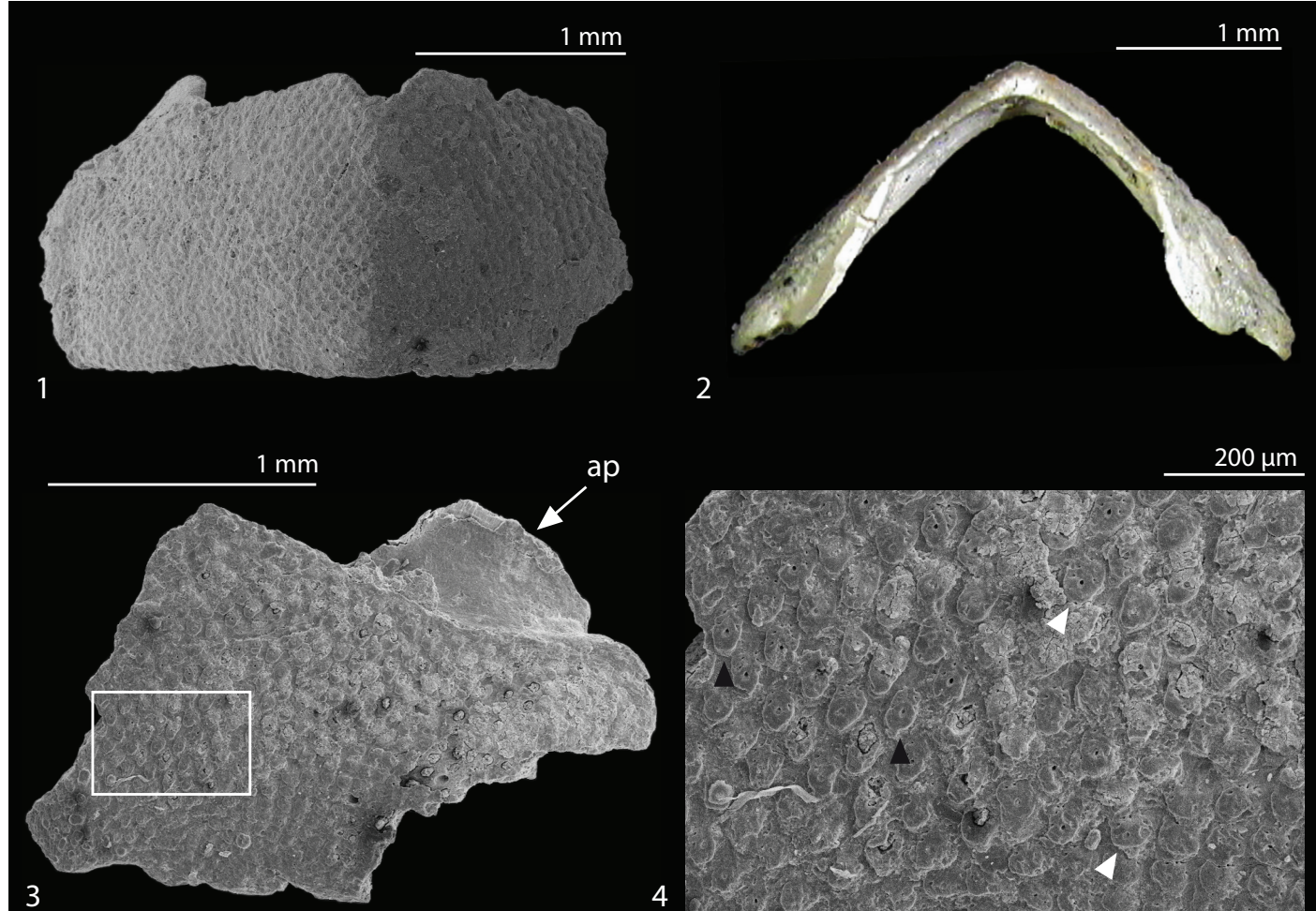

2
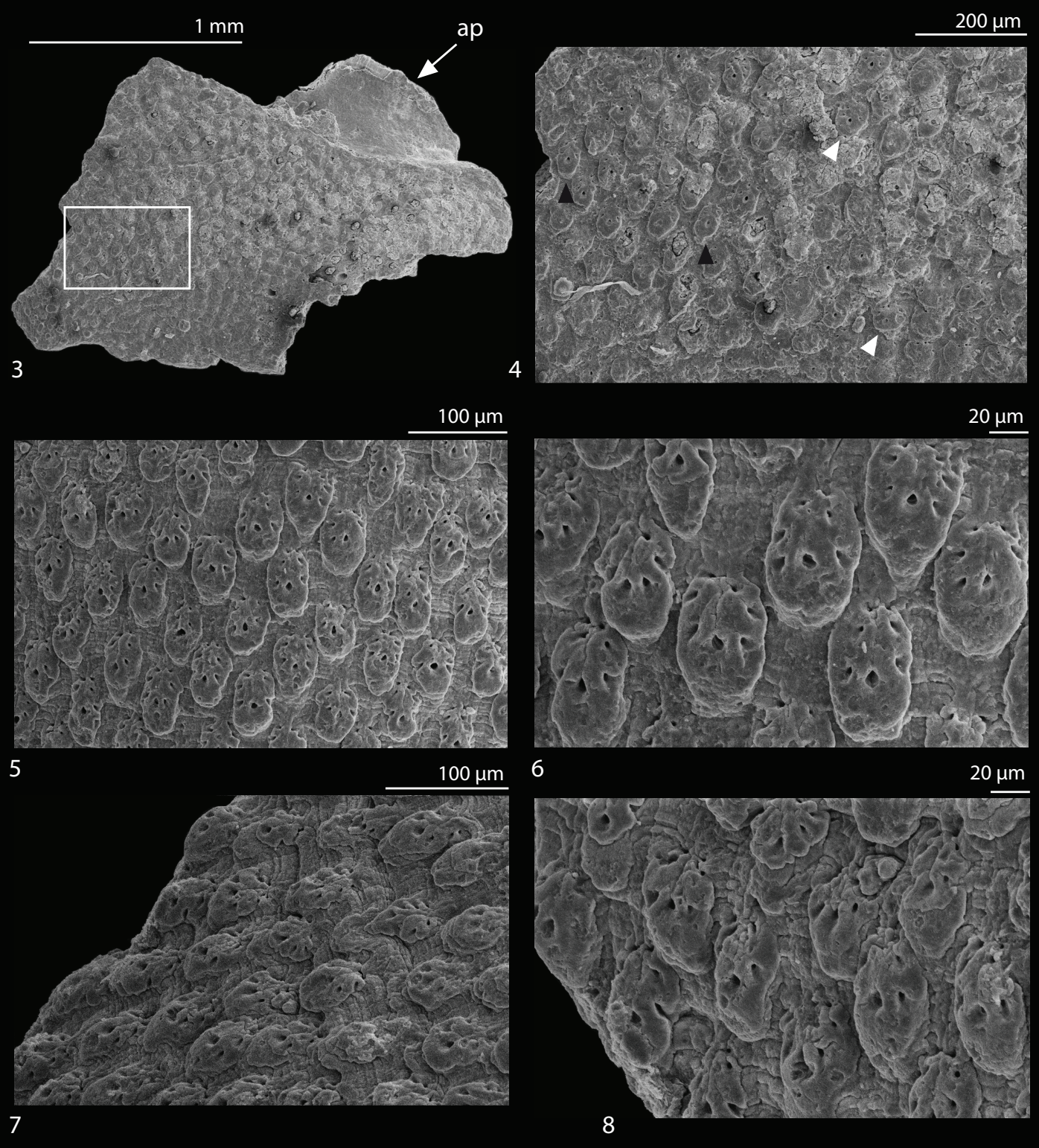

FIGURE 3. Leptochiton lignatilis n. sp., from the Miocene (Tortonian) of Torrente Cinghio (Parma, N Italy, type locality). 1-2. Paratype MZB 32033, intermediate valve in dorsal (1) and profile view (2). 3-4. Paratype NHMW 2014/0451/ 0001, fragment of a tail valve showing apophysis (ap in 3) and close-up (white rectangle in 3) showing variation in granule shape (4) from circular (white triangles) to elongate (black triangles). 5-8. Paratype MZPD MAL-2076, detail of a fragment of an intermediate valve showing granule arrangement $(5,7)$ and macro and microaesthetes $(6,8)$. 


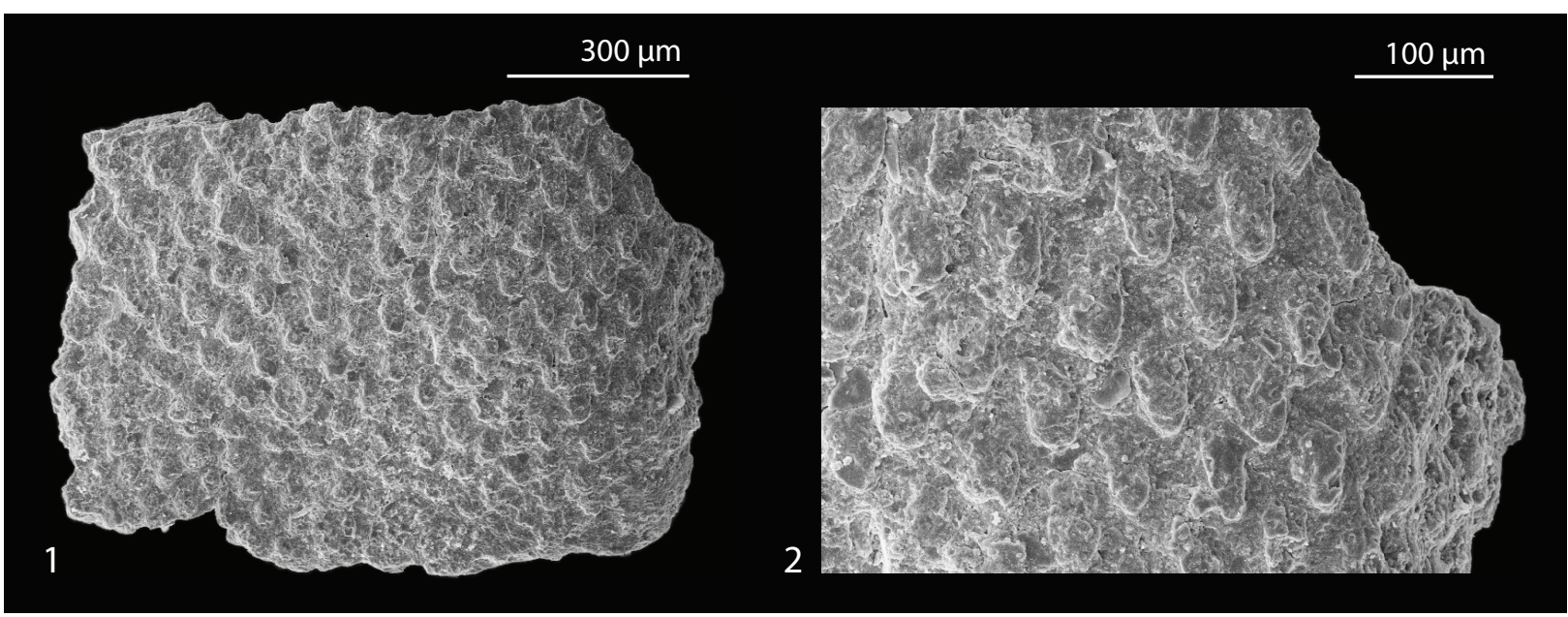

FIGURE 4. Leptochiton lignatilis $\mathrm{n}$. sp., from the Miocene (Langhian) of Moncasale di Casina (Reggio Emilia, N Italy). 1. Paratype MZPD MAL-2077, dorsal view of a fragment of an intermediate valve. 2. Close-up of the specimen as in Figure 4.1 showing granules.

Articulamentum without insertion laminae (Figure 2.2). Apophyses small, triangular in intermediate valves (Figure 3.1,3.3), more or less trapezoidal in tail ones (Figure 2.1, 2.3), widely separated by a large jugal sinus.

Remarks. In the material studied there are almost only small fragments of valves (of about 1-1.5 mm or less of width). Even though these fragmented valves have clearly visible tegmentum granules, in many cases it is not possible to identify them as head, intermediate or tail valves. Only 15 valves are complete or sufficiently complete.

The small fragment of the intermediate valve from Moncasale di Casina (Figure 4) has a sculpturing matching that of the material from Torrente Cinghio and is compatible with an attribution as Leptochiton. Considering the similarities of the sculpture, we provisionally consider this valve conspecific with the material from Torrente Cinghio.

Comparisons. The sculpture of Leptochiton's tegmentum is fundamentally of two types, fully covered with randomly or quincuncially arranged granules, or with granules arranged in longitudinal striae in central and antemucronal areas (and both randomly/quincuncially or in radial striae on head valve, lateral and postmucronal areas).

For Leptochiton species known from sunken woods (Sigwart and Sirenko, 2012, table 2), 12 of 23 have a tegmental sculpture that is comparable with Leptochiton lignatilis $\mathrm{n}$. sp. Five of them are less elevated, with a different shape of the tail valve and a subcentral mucro: Leptochiton angustidens Sigwart and Sirenko, 2012, L. consimilis Sigwart and Sirenko, 2012, L. schwabei Sigwart and Sirenko, 2012, L. deforgesi Sirenko, 2001 and L. vanbellei Sirenko, 2001 (the latter with a slightly anterior mucro). Six others are also less elevated and also have a different shape of the tail valves and have a subcentral mucro, but they also differ in having the granules in the central areas more or less arranged in distinctive longitudinal rows: Leptochiton benthedi (Leloup, 1981), L. rogeri Sigwart and Sirenko, 2015 (new name for L. clarki Sigwart and Sirenko, 2012, see Sigwart and Sirenko, 2015), L. longisetosus Sigwart and Sirenko, 2012, L. thandari Sirenko, 2001, L. vitjazi (Sirenko, 1977) and $L$. boucheti Sirenko, 2001 (the latter with a slightly anterior mucro).

Leptochiton kurnilatus Kaas, 1985 is a carinated and elevated species comparable with L. lignatils $\mathrm{n}$. sp. (height/width 0.57 vs. 0.5 ), but differs by the different shape and profile of tail valves, with the posterior mucro at about three quarters of the valve length.

Only three Leptochiton species from the Mediterranean Neogene have the same kind of tegmental sculpture, fully covered with randomly or quincuncially arranged granules. Leptochiton tavianii Dell'Angelo et al., 2004 from the Pliocene of Estepona (Spain) differs in having the granules characterized by a fungiform section and arranged in a beehive structure; $L$. salicensis Dell'Angelo and Bonfitto, 2005 from the Pleistocene of Salice (South Italy) has sturdier yet dissimilar valves, which are evenly rounded (subcarinated in L. lignatilis), a less elevated tail valve with a subcentral mucro (anterior in L. lignatilis) and more polygonal granules. The Pliocene-recent Leptochiton alveo- 
TABLE 1. Distribution and main characters of Leptochiton lignatilis n. sp., L. alveolus (M. Sars in Lovén, 1846) and $L$. belknapi Dall, 1878, allowing comparisons.

\begin{tabular}{|c|c|c|c|}
\hline $\begin{array}{c}\text { Distribution/taxonomic } \\
\text { characters }\end{array}$ & $\begin{array}{l}\text { Leptochiton } \\
\text { lignatilis } \mathrm{n} . \mathrm{sp} .\end{array}$ & L. alveolus & L. belknapi \\
\hline Stratigraphy & Miocene of Italy & Pliocene of Italy & - \\
\hline Biogeography & - & Atlantic Ocean & Pacific and Indian Oceans \\
\hline Valves & Thinner and fragile & Thinner and fragile & Thicker and sturdy \\
\hline Tegmental granules & $\begin{array}{l}\text { Irregular, rounded- } \\
\text { subquadrangular } \\
\text { shape }\end{array}$ & $\begin{array}{l}\text { More regular, smaller and closely } \\
\text { packed, rounded-oval shape }\end{array}$ & $\begin{array}{l}\text { Larger and more widely spaced, oval } \\
\text { to diamond-like in shape }\end{array}$ \\
\hline Intermediate valves (IV) & Rectangular & Rectangular & Rectangular \\
\hline IV back & Carinated & Arched & Carinated \\
\hline IV anterior margin & Almost straight & Concave in the jugal area & Almost straight \\
\hline IV posterior margin & $\begin{array}{l}\text { Almost straight, apex } \\
\text { not distinct }\end{array}$ & $\begin{array}{c}\text { Almost straight, apex obsolete or } \\
\text { poorly marked }\end{array}$ & $\begin{array}{l}\text { Almost straight, obsolete or poorly } \\
\text { marked }\end{array}$ \\
\hline IV lateral areas & Not raised & Not raised & $\begin{array}{l}\text { Little raised, distinctly marked by a } \\
\text { diagonal depression }\end{array}$ \\
\hline IV height/width ratio & 0.50 & - & 0.36 \\
\hline Tail valve (TV) & More than semicircular & Semicircular & Semicircular to roughly triangular \\
\hline TV anterior margin & Convex & Almost straight & Convex \\
\hline TV mucro & Anterior & Central & Subcentral \\
\hline
\end{tabular}

lus (M. Sars in Lovén, 1846) is characterized by the tegmentum covered with pronounced, neatly separated, rounded to oval granules, more or less distinctly quincuncially arranged on all the valves surface, the lateral areas indiscernible from the central areas and arched intermediate valves (see Kaas, 1981 for a detailed description). This deepwater chiton, and secondarily the distinct Leptochiton belknapi Dall, 1878 (Wu and Okutani, 1984), are the most comparable species to L. lignatils $\mathrm{n}$. sp. Differences between these species are summarized in Table 1. The specimen reported as " $L$. alveolus" from Eocene-Oligocene cold-seep limestones of the Olympic Peninsula, Washington (Goedert and Campbell, 1995; Squires and Goedert, 1995; Peckmann et al., 2002) has not been considered for this comparison because its specific and even generic assignment remains an open problem (Schwabe and Sellanes, 2010). However, geographic and stratigraphic separation of this specimen from $L$. lignatils $\mathrm{n}$. sp. allows considering them as different species.

\section{DISCUSSION AND CONCLUDING REMARKS}

Preliminary results of studies on several Neogene deep-sea wood-fall deposits from Emilia ( $\mathrm{N}$ Italy) suggest that each of the molluscan assemblages has a highly distinctive biota (Bertolaso, personal observation). However, all of these assemblages are characterized by a taxonomic composition comparable to those observed in analogous modern environments. More generally, in the chemosynthetic communities, there is broad overlap in community composition at generic and higher taxonomic ranks. In contrast, the unique biodiversity of each assemblage at lower (species/ genus) taxonomic ranks appears to be mostly related to the depositional depth. These observations support the hypothesis that deep-sea woodfalls are a mixture of endemic and generalist taxa, and their composition may be related to the depositional setting as suggested by Kiel and Little (2006) for deep-sea seep molluscs as well as to the palaeogeographic dynamics that changed the Miocene Proto-Mediterranean-Atlantic Region to the recent Mediterranean basin (Harzhauser et al., 2002).

The most abundant molluscs in the studied samples from the Torrente Cinghio are Pseudonina bellardii (Michelotti, 1847) and Homalopoma sp. The former belongs to a typical deep-sea genus of the Neogene wood-falls (Bertolaso and Palazzi, 1994). The latter belongs to Colloniidae Cossmann, 1917, a typical family from late Mesozoicrecent chemosynthesis-based communities (e.g., Kiel, 2008; Gill et al., 2005; Kaim et al., 2009; Sasaki et al., 2010; Gracia et al., 2012), and is the same species as found in other Miocene wood-falls from northern Italy (Bertolaso, personal observation). Two other remarkable occurrences, both represented by a significant number of specimens, contribute to detailing a palaeoenvironmental 
framework. The first, Leptochiton, is a typical woodfall genus in deep waters. The second is Idas Jeffreys, 1876, a typical bivalve from chemosynthetic environments, common in wood-fall communities since the Eocene (e.g., Kiel and Goedert, 2006b; Pailleret et al., 2007; Bienhold et al., 2013). This four-taxa assemblage illustrates a typical wood-fall molluscan association in deep-sea chemosynthetic ecosystems. The deep environmental setting is supported by the occurrence of other species, such as the scaphopod Entalina tetragona and the scallop Delectopecten cf. vitreus. All the chiton material found belongs to the new species described, Leptochiton lignatilis $\mathrm{n}$. $\mathrm{sp}$., representing a genus that is common on sunken wood in tropical recent waters. The fossil record Leptochiton from these assemblages, however, is quite sparse. Aside from the type locality, this species is known only from one incomplete intermediate valve (a small fragment) found at the Moncasale di Casina site. The only diagnostic character of this valve is the tegmental sculpture comparable to that observed in the material from Torrente Cinghio, thus suggesting a conspecificity. In the same site were rare valves of Teredinidae and some specimens of Homalopoma sp. and Pseudonina bellardii. This association points to the occurrence of a wood-fall community similar to that of Torrente Cinghio, but represented by scattered specimens displaced from their natural habitat.

It is noteworthy that no Xylophagidae, only Teredinidae (Psiloteredo Bartsch, 1922, Teredothyra Bartsch, 1921, Bankia Gray, 1842) boring bivalves were found in the fossil wood-fall association studied from the Torrente Cinghio. Likewise, only teredinid remains were found at the Moncasale di Casina site. As already discussed, xylophagid bivalves are known to have been a fundamental component in wood-fall settings hosting chemosynthetic communities since at least the Cretaceous. Their decomposing faecal pellets significantly increase the amount of sulphide around sunken wood (Kaim, 2011 and references therein). In the studied case, neither Teredinidae colonization of wood during a floating stage nor after sinking can be definitely determined. There is evidence, however, of a chemosynthetic community originating on the deep-sea floor in the presence of living Teredinidae: 1) the co-occurrence of Idas, a genus never found alive on floating woods; and 2) the presence of taxa that are typical of deep sea and wood-fall ecosystems and are represented by a full growth series, conditions that are possible in the wood-fall communities due to the ecological role carried out by the xylophagous bivalves. Our studied material has unexpectedly implied a colonization of sunken wood by Teredinidae, not anticipated in previous literature. The central role for Teredinidae apparently did not hamper the development of a specialized fauna in a deep-sea reducing environment, analogous to xylophagid dominated assemblages. It could be hypothesized that Teredinidae species, at least in the Mediterranean area, were previously living in deeper waters and have only recently been replaced by Xylophagidae; however, only a quantitatively exhaustive dataset on Neogene deep wood-fall communities could endorse this hypothesis. Futures studies on similar deposits/communities from Emilia Romagna ( $\mathrm{N}$ Italy) will likely shed some more light on the role of Teredinidae in this kind of ecosystem.

\section{ACKNOWLEDGEMENTS}

Our special thanks to C. Pizzaferri (Parma, Italy) who revealed us the Torrente Cinghio site and provided useful literature. We are grateful to $B$. Sirenko (ZISP) for the helpful discussion on Leptochiton lignatilis n. sp.; to S. Dominici (Museo di Storia Naturale, University of Firenze, Italy) for helpful comments that improved an early draft of the manuscript; to $S$. Cavagna (Dipartimento di Scienze della Terra dell'Università di Torino, Italy) for helping with preliminary SEM analysis. D.J. Eernisse (California State University, Fullerton, USA) and an anonymous reviewer are sincerely thanked for their helpful and constructive comments.

\section{REFERENCES}

Amorosi, A., Colalongo, M.L., and Vaiani, S.C. 1993. Le unità epiliguri nel settore emiliano dell'Appennino settentrionale. Biostratigrafia, stratigrafia sequenziale e implicazioni litostratigrafiche. Paleopelagos, 3:209240.

Aradas, A. and Maggiore, C. 1844. Catalogo ragionato delle conchiglie viventi e fossili di Sicilia. Atti dell'Accademia Gioenia di Scienze Naturali, 20:101142, 343-360.

Bartsch, P. 1921. A new classification of the shipworms and descriptions of some new wood boring mollusks. Proceedings of the Biological Society of Washington, 34:25-32.

Bartsch, P. 1922. A monograph of the American shipworms. U.S. National Museum Bulletin, 122:1-51.

Berg, C.J. Jr., Butman, B., Early, J.A., and Turner, R.D. 1987. Seasonal recruitment of marine invertebrates to hard substrates on Georges Bank and the eastern 
continental shelf of the United States. The Nautilus, 101:19-24.

Bernardino, A.F., Smith, C.R., Baco, A., Altamira, I., and Sumida, P.Y.G. 2010. Macrofaunal succession in sediments around kelp and wood-falls in the deep NE Pacific and community overlap with other reducing habitats. Deep Sea Research, 57:708-723.

Bertolaso, L. and Palazzi, S. 1994. La posizione sistematica di Delphinula bellardii (Michelotti, 1847). (Appunti di malacologia neogenica: 2). Bollettino Malacologico, 29:291-302.

Bettelli, G., Bonazzi, U., Fazzini, P., and Panini, F. 1989. Schema introduttivo alla geologia delle Epiliguridi dell'Appennino modenese e delle aree limitrofe. Memorie della Società Geologica Italiana, 39:215244.

Bienhold, C., Pop Ristova, P., Wenzhöfer, F., Dittmar, T., and Boetius, A. 2013. How Deep-Sea wood-falls Sustain Chemosynthetic Life. Plos ONE 8 (1):e53590. doi:10.1371/journal.pone.0053590

Blow, W.H. 1956. Origin and evolution of the foraminiferal genus Orbulina d'Orbigny. Micropaleontology, 2:57-70.

Boone, L. 1928. Scientific results of the first Oceanographic Expedition of the "Pawnee", 1925. Mollusca from tropical East American Seas. Bulletin of the Bingham Oceanographic Collection, 1(3):1-20.

Brocchi, G.B. 1814. Conchiologia Fossile Subappenninica con Osservazioni Geologiche sugli Appennini e sul Suolo Adiacente. Stamperia Reale, Milano.

Clark, R.N. 2008. Two new chitons of the genus Tripoplax from the Monterey Sea Canyon. American Malacological Bulletin, 25(1):77-86.

Cossmann, M. 1917. Éocène de Bretagne. Faune de Bois-Gouët. Atlas Paléontologique. Hermann \& Fils, Paris.

Dall, W.H. 1878. Report on the limpets and chitons of the Alaskan and Arctic regions, with descriptions of genera and species believed to be new. Proceedings of the United States National Museum, 1:281-344.

Dall, W.H. 1882. On certain limpets and chitons from the deep waters off the eastern coast of the United States. Proceedings of the United States National Museum, 4:400-414.

Dall, W.H. 1889. Report on the results of dredging, under the supervision of Alexander Agassiz, in the Gulf of Mexico (1877-78) and in the Caribbean Sea (187980 ), by the United States Coast Survey Steamer "Blake," Lieutenant-Commander C.D. Sigsbee, U.S.N., and Commander J.R. Bartlett, U.S.N., commanding. Report on the Mollusca, Pt. 2: Gastropoda and Scaphopoda. Bulletin of the Museum of Comparative Zoology, 18:1-492.

Dell'Angelo, B. and Bonfitto, A. 2005. Notes on Fossil Chitons. 1. A new species of Lepidopleurus (Mollusca: Polyplacophora) from the Pleistocene of Salice (Sicily, Italy). Zootaxa, 821:1-6.

Dell'Angelo, B., Landau, B., and Marquet, R. 2004. Polyplacophora from the Early Pliocene of Estepona
(Málaga, southwest Spain). Bollettino Malacologico, suppl. 5:25-44.

Dell'Angelo, B. and Palazzi, S. 1991. Considerazioni sulla famiglia "Leptochitonidae" Dall 1889 (Mollusca, Polyplacophora). IV. Aggiunte e correzioni. Bollettino Malacologico, 27:35-38.

Dell'Angelo, B. and Smriglio, C. 1999. Chitoni Viventi del Mediterraneo. Edizioni Evolver, Rome.

Di Dio, G., Lasagna, S., Martini, A., and Zanzucchi, G. (eds.) 2005. Note illustrative della Carta Geologica d'Italia alla scala 1:50000. Foglio 199, Parma sud.

Di Dio, G. and Zanzucchi, G. (Scientific Coordinators). 2005. Carta Geologica d'Italia, Foglio 199, Parma sud. Scala 1:50000. Regione Emilia Romagna, Servizio Geologico, Sismico e dei Suoli. S.EL.CA, Firenze. Available at http://www.isprambiente.it/ Media/carg/199_PARMA_SUD/Foglio.html

Di Stefano, A., Foresi, L.M., Lirer, F., laccarino, S.M., Turco, E., Amore, F.O., Mazzei, R., Morabito, S., Salvatorini, G., and Aziz, H.A. 2008. Calcareous plankton high resolution bio-magnetostratigraphy the for Langhian of Mediterranean Area. Rivista Italiana di Paleontologia e Stratigrafia, 114:51-76.

Distel, D.L., Baco, A.R., Chuang, E., Morril, W., Cavanaugh, C., and Smith, C.R. 2000. Marine ecology: Do mussels take wooden steps to deep-sea vents? Nature, 403:725-726.

Duperron, S., Pottier, M.-A., Léger, N., Gaudron, S.M., Puillandre, N., Le Prieur, S., Sigwart, J.D., Ravaux, J., and Zbinden, M. 2013. A tale of two chitons: is habitat specialisation linked to distinct associated bacterial communities? FEMS Microbiology Ecology, 83:552-567.

Edmondson, C.H. 1962. Teredinidae, Ocean Travelers. Occasional Papers of Bernice P. Bishop Museum, 23:45-59.

Edward, D.G. and Freundt, E.A. 1967. Proposal for Mollicutes as name of the class established for the order Mycoplasmatales. International Journal of Systematic Bacteriology, 17:267-268.

Forbes, E. and Hanley, S.C. 1848. A History of British Mollusca and their Shells. Vol. 1. Van Voorst, London.

Fornaciari, E., Di Stefano, A., Rio, D., and Negri, A. 1996. Middle Miocene quantitative calcareous nannofossil biostratigraphy in the Mediterranean region. Micropaleontology, 42:37-63.

Gasperi, G., Bettelli, G., Panini, F., and Pizziolo, M. 2005. Note illustrative della Carta Geologica d'Italia alla scala 1:50000. Foglio 219, Sassuolo.

Gill, F.L., Harding, I.C., Little, C.T.S. A., and Todd, J.A. 2005. Palaeogene and Neogene cold seep communities in Barbados, Trinidad and Venezuela: An overview. Palaeogeography, Palaeoclimatology, Palaeoecology, 227:191-209.

Gmelin, J.F. 1791. Systema Naturae per Regna Tria Naturae. Editio decima tertia. Vol. 1. Beer, Lipsiae (Leipzig). 
Goedert, J.L. and Campbell, K.A. 1995. An early Oligocene chemosynthetic community from the Makah Formation, northwestern Olympic Peninsula, Washington. The Veliger, 38:22-29.

Gracia, A. and Ardila, N.E. 2004. Notas sobre el quiton Leptochiton binghami (Boone, 1828) (Mollusca: Polyplacophora) en el Caribe Colombiano. Boletin de Investigaciones Marinas y Costeras, 33:275-278.

Gracia, A., Rangel-Buitrago, N., and Sellanes, J., 2012. Methane seep molluscs from the Sinú - San Jacinto fold belt in the Caribbean Sea of Colombia. Journal of the Marine Biological Association of the United Kingdom, 92:1367-1387.

Gray, J.E. 1821. A natural arrangement of Mollusca according to their internal structure. London medical Repository, 15:229-239.

Gray, J.E. 1842. Synopsis of the Content of the British Museum, Forty-fourth edition. Woodfall \& Son, London.

Gray, J.E. 1847. Additional observations on the chitones. Proceedings of the Zoological Society of London, 15:126-127.

Haderlie, E.C. and Mellor, J.C. 1973. Settlement, growth rates and depth preference of the shipworm Bankia setacea (Tryon) in Monterey Bay. The Veliger, 15:265-286.

Harzhauser, M., Piller, W.E., and Steininger, F. 2002. Circum-Mediterranean Oligo-Miocene biogeographic evolution - the gastropods' point of view. Palaeogeography, Palaeoclimatology, Palaeoecology, 183:103-133.

Heise, E.A., Raymond, A., Parson-Hubbard, K., Walker, S.E., Staff, G., Powell, E.A., Brett, C., and AshtonAlcox, K.A. 2011. Wood taphonomy in a tropical marine carbonate environment: Experimental results from Lee Stocking Island, Bahamas. Palaeogeography, Palaeoclimatology, Palaeoecology, 312:363379.

laccarinio, S. and Salvatorini, G. 1982. A framework of planktonic foraminiferal biostratigraphy for early Miocene to late Pliocene Mediterranean area. Paleontologia ed Evoluzione, 2:115-125.

Jeffreys, J.G. 1876. New and peculiar Mollusca of the Pecten, Mytilus and Arca families procured in the 'Valorous' Expedition. Annals and Magazine of Natural History, 4:424-436.

Kaas, P. 1981. Scandinavian species of Leptochiton Gray, 1847 (Mollusca: Polyplacophora). Sarsia, 66:217-229.

Kaas P. 1985. Chitons (Mollusca: Polyplacophora) procured by the French Benthedi Expedition, 1977, and the MD 32- Reunion-Expedition, 1982, in the southwestern Indian Ocean. Zoologische Medededelingen, 59:321-340.

Kaas, P. and Van Belle, R.A. 1985. Monograph of Living Chitons (Mollusca, Polyplacophora). Volume 1. E.J. Brill/Dr. W. Backhuys, Leiden.

Kaim, A. 2011. Non-actualistic wood-fall associations from Middle Jurassic of Poland. Lethaia, 44:109-124.
Kaim, A., Jenkins, R.G., and Hikida, Y. 2009. Gastropods from Late Cretaceous Omagari and Yasukawa hydrocarbon seep deposits in the Nakagawa area, Hokkaido, Japan. Acta Palaeontologica Polonica, 54:463-490.

Kaim, A., Kobayashi, Y., Echizenya, H., Jenkins, R.G., and Tanabe, K. 2008. Chemosynthesis-based associations on Cretaceous plesiosaurid carcasses. Acta Palaeontologica Polonica, 53:97-104.

Kiel, S. and Little, C.T.S. 2006. Cold-seep mollusks are older than the general marine mollusk fauna. Science, 313:1429-1431.

Kiel, S. 2008. Fossil evidence for micro- and macrofaunal utilization of large nekton-falls: Examples from early Cenozoic deep-water sediments in Washington State, USA. Palaeogeography, Palaeoclimatology, Palaeoecology, 267:161-174.

Kiel, S. and Goedert, J.L. 2006a. Deep-sea food bonanzas: Early Cenozoic whale-fall communities resemble wood-fall rather than seep communities. Proceedings of the Royal Society B, 273:2625-2631.

Kiel, S. and Goedert, J.L. 2006b. A wood-fall association from Late Eocene deep-water sediments of Washington State, USA. Palaios, 21:548-556.

Kuroda, T. 1943. Akebiconcha, a new pelecypod genus. Venus, 13:14-18. (partly in Japanese)

Leloup, E. 1981. Résultats des campagnes Musorstom I: Philippines (18-28 Mars 1976): Mollusques: Polyplacophores. Mémoires Orstom, 91:317-323.

Linnaeus, C. 1767. Systema Naturae per Regna Tria Naturae, Secundum Classes, Ordines, Genera, Species, cum Characteribus, Differentiis, Synonymis, Locis. Editio duodecimam, reformatam. I. Regnum Animale. Pt. 2. Holmiae.

Lovén, S. 1846. Nordens Hafs-Mollusker. Index Mol- luscorum litora Scandinaviae occidentalia habitan- tium. Öfversigt af Kongliga Vetenskaps-Akademiens Förhandlingar, 3:134-161, 182-204.

Lundsten, L., Schlining, K.L., Frasier, K., Johnson, S.B., Kuhnz, L.A., Harvey, J.B., Clague, G., and Vrijenhoek, R.C. 2010. Time-series analysis of six whalefall communities in Monterey Canyon, California, USA. Deep-Sea Research I, 57:1573-1584.

McClain, C.R. and Barry, J. 2014. Beta-Diversity on Deep-Sea wood-falls Reflects Gradients in Energy Availability. Biology Letters, 10: 20140129. doi: 10.1098/rsbl.2014.0129v.

McKoy, J.L. 1980. Distribution of shipworms (Bivalvia: Teredinidae) in the New Zealand region. New Zealand Journal of Marine and Freshwater Research, 14:263-275.

Michelotti, G. 1847. Descriptions des fossils des terrains miocenes de l'Italie septentrionale. Natuurkundige Verhandelingen van de Hollandsche Maatschappij der Wetenschappen te Haarlem, 2(3):1-408.

Miculan, P. 1992. Gli ostracodi del Miocene superiore di Vigoleno (subappennino piacentino). Bollettino della Società Paleontologica Italiana, 31:105-132. 
Montagu, G. 1803. Testacea Britannica or Natural History of British Shells, Marine, Land and Fresh Water, Including the Most Minute, Systematically Arranged and Embellished with Figures. Vol. 1. [Privately published], London.

Nair, N.B. and Saraswathy, M. 1971. The biology of wood-boring teredinid molluscs. Advance in marine Biology, 9:335-509.

Nierstrasz, H.F. 1905. Die Chitonen der Siboga Expedition. Siboga Expeditie Monograph, 48:1-112.

Pailleret, M., Haga, T., Petit, P., Privé-Gill, C., Saedlou, N., Gaill, F., and Zbinden, M., 2007. Sunken wood from the Vanuatu Islands: identification of wood substrates and preliminary description of associated fauna. Marine Ecology, 28:233-241.

Papani, G. (Scientific Coordinator) 2002. Carta Geologica d'Italia, Foglio 218, Castelnovo ne' Monti. Scala 1:50000. Regione Emilia Romagna, Servizio Geologico, Sismico e dei Suoli. S.EL.CA, Firenze. Available at http://www.isprambiente.it/Media/carg/218_CASTELNOVO_NE_MONTI/Foglio.html

Peckmann, J., Goedert, J.L., Thiel, V., Michaelis, W., and Reitner, J. 2002. A comprehensive approach to the study of methane-seep deposits from the Lincoln Creek Formation, western Washington State, USA. Sedimentology, 49:855-873.

Pilsbry, H.A. 1893. Manual of Conchology; Structural and Systematic, with Illustrations of the Species. Vol. 15. Polyplacophora, (Chitons.) Acanthochitidae, Cryptoplacidae and Appendix. Tectibranchiata. Academy of Natural Sciences, Conchological Section, Philadelphia.

Purchon, R.D. 1941. On the biology and relationships of the lamellibranch Xylophaga dorsalis (Turton). Journal of the Marine Biological Association of the United Kingdom 25:1-39.

Quayle, D.B. 1992. Marine Wood Borers in British Columbia. Canadian Special Publication of Fisheries and Aquatic Sciences, 115:1-55.

Rafinesque, C.S. 1815. Analyse de la Nature, ou Tableau de I'Univers et des Corps Organisés. Tipografia Giovanni Barravecchia, Palermo.

Raymond, P.E. 1910. A preliminary list of the fauna of the Allegheny and Conemaugh series in western Pennsylvania. Annals of the Carnegie Museum, 7:144-158.

Ryan, W.B.F., Sibuet, J.-C., Arthur, M.A., Lopatin, B.G., Moore, D.G., Maldonado, A., Rehault, J.-P., laccarino, S., Sigal, J., Morgan, G.E., Blechschmidt, G., Williams, C.A., Johnson, D., Barnes, R.O., and Habib, D. 1979. Site 398. Deep Sea Drilling Project, 47:25-233.

Saito, H. 2013. A new species of Lepidozona (Mollusca, Polyplacophora, Ischnochitonidae) from Okinawa Trough, East China Sea. Bulletin of the National Museum of Nature and Science (A), 39:5-10.

Samadi, S., Corbari, L., Lorion, G., Hourdez, S., Haga, T., Dupont, J., Boisselier, M.-C., and Richer de Forges, B. 2010. Biodiversity of deep-sea organisms associated with sunken-wood or other organic remains sampled in the tropical Indo-Pacific. Cahiers de Biologie Marine, 51:459-466.

Santhakumaran, L.N. and Sneli, J.A. 1984. Studies of the marine fouling and wood-boring organisms of the Trondheimsfjord (Western Norway). Gunneria, 48:136.

Sasaki, T., Warén, A., Kano, Y., Okutani, T., and Fujikura, K. 2010. Gastropods from Recent Hot Vents and Cold Seeps: Systematics, Diversity and Life Strategies. Chapter 7, p. 169-254. In Kiel, S. (ed.), The Vent and Seep Biota, Topics in Geobiology 33. Springer Science+Business Media B.V. 2. doi: 10.1007/978-90-481-9572-5_7

Schwabe, E., Bartsch, I., Błażewicz-Paszkowycz, M., Brenke, N., Chernyshev, A.V., Elsner, N.O., Fischer, V., Jażdżewska, A., Malyutina, M.V., Miljutin, D., Miljutina, M., Kamenev, G.M., Karanovic, I., Maiorova, A., and Würzberg, L. 2015. Wood-associated fauna collected during the KuramBio-expedition in the North West Pacific. Deep-Sea Research Part II: Tropical Studies in Oceanography, 111:376-388.

Schwabe, E. and Sellanes, J. 2004. A new species of Lepidozona (Mollusca: Polyplacophora: Ischnochitonidae), found on whale bones off the coast of Chile. Iberus, 22:147-153.

Schwabe, E. and Sellanes, J. 2010. Revision of Chilean bathyal chitons (Mollusca: Polyplacophora) associated with cold-seeps, including description of a new species of Leptochiton (Leptochitonidae). Organisms Diversity and Evolution, 10:31-55.

Scrocca, D., Doglioni, C., and Innocenti, F. 2003. Contraints for an interpretation of the italian geodynamics: a review. Memorie Descrittive alla Carta Geologica d'Italia, 62:15-46.

Sigwart, J.D. 2009. The deep-sea chiton Nierstraszella (Mollusca: Polyplacophora: Lepidopleurida) in the West Pacific: taxonomy, morphology, and a bizarre ectosymbiont. Journal of Natural History, 43:447-468.

Sigwart, J.D., Schwabe, E., Saito, H., Samadi, S., and Giribet, G. 2011. Evolution in the deep sea: a combined analysis of the earliest diverging living chitons (Mollusca: Polyplacophora: Lepidopleurida). Invertebrate Systematics, 24:560-572.

Sigwart, J.D. and Sirenko, B.I. 2012. Deep-sea chitons from sunken wood in the West Pacific (Mollusca: Polyplacophora: Lepidopleurida): taxonomy, distribution, and seven new species. Zootaxa, 3195:1-38.

Sigwart, J.D. and Sirenko, B.I. 2015. A new name for the deep-sea chiton Leptochiton clarki Sigwart \& Sirenko non Berry (Lepidopleurida: Leptochitonidae). Zootaxa, 3986: 249-250. dx.doi.org/10.11646/zootaxa.3986.2.9

Sirenko, B.I. 1977. Vertical distribution of chitons of the genus Lepidopleurus (Lepidopleuridae) and its new ultraabyssal species. Zoologicheskij Zurnal, 61:11071110.

Sirenko, B.I. 1988. A new genus of deep sea chitons Ferreiraella gen. n. (Lepidopleurida, Leptochitonidae) 
with a description of a new ultra-abyssal species. Zoological Journal, 67:1776-1786.

Sirenko, B.I. 1992 Nierstraszellidae fam. nov.-a new family of chitons (Polyplacophora, Lepidopleurida) from the bathyal Western Pacific. Ruthenica, 2:8190.

Sirenko, B.I. 2001. Deep-sea chitons (Mollusca, Polyplacophora) from sunken wood off New Caledonia and Vanuatu. Mémoires du Muséum national d'Histoire Naturelle, 185:39-71.

Sirenko, B.I. 2004. The ancient origin and persistence of chitons (Mollusca, Polyplacophora) that live and feed on deep submerged land plant matter (xylophages). Bollettino Malacologico Suppl. 5:109-114.

Sirenko, B.I. 2013. Four new species and one new genus of Jurassic chitons (Mollusca: Polyplacophora: Lepidopleurida) from the Middle Russian Sea. Proceedings of the Zoological Institute RAS, 317:30-44.

Smith, E.A. 1906. Natural history notes H.M. marine survey steamer "Investigator" commander T.H. Heming, R.N. Series III. No. 10. On Mollusca from the Bay of Bengal and the Arabian Sea. Annals and Magazine of Natural History, 43:245-264.

Squires, R.L. and Goedert, J.L. 1995. An extant species of Leptochiton (Mollusca: Polyplacophora) in Eocene and Oligocene cold-seep limestones, Olympic Peninsula, Washington. The Veliger, 38:47-53.

Thiele, J. 1909. Revisions des Systems der Chitonen. Zoologica, 1:1-70.

Turner, R.D. 1968 The Xylophagainae and the Teredinidae - a study in contrasts. Annual Report of the American Malacological Union for 1967:46-48.
Turner, R.D. 1973. Wood-boring bivalves, opportunistic species in the deep sea. Science, 180:1377-1379.

Turner, R.D. 1978. Wood, mollusks, and deep-sea food chains. Bulletin of the American Malacological Union for 1977:13-19.

Turner, R.D. 2002. On the subfamily Xylophagainae (Family Pholadidae, Bivalvia, Mollusca). Bulletin of the Museum of Comparative Zoology, 157:223-307.

Voight, J.R. 2007. Experimental deep-sea deployments reveal diverse Northeast Pacific wood-boring bivalves of Xylophagainae (Myoida: Pholadidae). Journal of Molluscan Studies, 73:377-391.

Voight, J.R. 2015. Xylotrophic bivalves: aspects of their biology and the impacts of humans. Journal of Molluscan Studies, 81:175-186.

von Middendorff, A.F. 1847. Beiträge zu einer Malakozoologia Rossica. Mémoires des Sciences Naturales de l'Académie Impériale de St. Pétersbourg, 6:1-151.

Wolff, T. 1979. Macrofaunal utilization of plant-remains in the deep sea. Sarsia, 64:117-136.

Wu, S.-K. and Okutani, T. 1984. The deepsea chitons (Mollusca: Polyplacophora) collected by the R/V Soyo-Maru from Japan. - I. Lepidopleuridae. Venus, 43:1-31.

Zbinden, M., Pailleret, M., Ravaux, J., Gaudron, S., Hoyoux, C., Lorion, J., Halary, S., Warén, A., and Duperron, S. 2010. Bacterial communities associated with the wood-feeding gastropod Pectinodonta sp. (Patellogastropoda, Mollusca). FEMS Microbiology Ecology, $74: 450-463$. 